\title{
Attitude of Adults towards HIV Screening (A Case Study of Isuada Community, Owo, Ondo State, Nigeria)
}

\author{
Article by Fasoranti, Abimbola Bosede \\ BSN-MSN, Texila American University, Guyana, \\ E-mail: abimfash4god79@gmail.com
}

\begin{abstract}
This is a study on attitude of adults towards HIV screening. The study was carried out in Isuada community Owo, Ondo State Nigeria. The deadly nature of this disease and late presentation of clients to the hospital despite the advocacy and awareness created through the media prompted the researcher to carry out this research. The main objective of this study is to examine the knowledge of people in Isuada community about HIV Screening, to investigate possible barrier to accepting HIV screening and correct negative notion about this investigation. Data was obtained through a structured questionnaire schedule. Same was administered to adult respondents in Isuada community in Owo Local Government Area using multi-staged random sampling. Multi-staged random sampling involved selection of the sample or sampling plans where the sampling is carried out in stages using smaller and smaller sampling units at each stage from the community, wards, streets, house hold in the selected community. Sample size is 100. Data were analysed by the use of statistical tools and same presented in tables and charts, while chi- square and correlation coefficient were used to test hypothesis. The findings of study shows that $94 \%$ of the respondents are aware of this deadly disease, $85 \%$ are aware of the screening being carried out to diagnose it, but only $37 \%$ of the respondents have been screened before. Among those that have not been screened female had the highest percentage $55.6 \%$, which shows that there is poor utilization of government hospitals by these women. Majority of those that are yet to be screen said they have not heard about HIV Screening before $23.82 \%$ and some does not see any need for it $22.22 \%$ (Table 4.12). The summary of my other findings and recommendation were made below.
\end{abstract}

\section{Introduction}

Human Immunodeficiency Virus/Acquired immunodeficiency syndrome (HIV/AIDS) is a global pandemic. It is estimated that 33.2 million (30.6 - 36.1 million) people are infected worldwide, of which 15.4 million (13.9 - 16.6 million) are women. Sub-Saharan Africa is home to 22 million HIV infected persons (70\% of the world infected population) and new infections in 2007 were 2.5 million (1.8 - 4.1 million) people. Deaths due to AIDS were 3.1 million for the year 2005 while deaths of children under 15years were 330,000 (310,000 - 380,000).

The global AIDS epidemic is one of the greatest challenges facing our generation. AIDS is a new type of global emergency an unprecedented threat to human development requiring sustain education and commitment over the long term.” stated Kofi Annan, (2003). Statistics compiled by UNAIDS (2006) confirm that since the start of the pandemic, almost 60 million people have been infected with HIV/AIDS worldwide.

HIV/AIDS is one of the leading causes of death in this region; worldwide it is the fourth-largest killer. It is estimated that 37.8 million people are currently living with HIV, indicating that the virus is not yet under control.

Control measures in response to this epidemic have been successful in some parts of the region, Uganda and Senegal being good examples. Uganda has brought estimated prevalence rate down to 5\% by the end of 2001 from an estimated peak of close to 14\% in the early 1990s with strong prevention campaigns. HIV prevalence has stabilized in Senegal at a relatively low level. 
Among the measures responsible for this success is the introduction of programmes of voluntary counselling and testing (VCT). Evidences from research in both developed and developing countries show that VCT leads to earlier access to HIV therapy, which in turn increases its effectiveness. It also reduces risk behaviour. In many countries VCT programmes are playing an increasing part in prevention and care strategies.

\section{Background of the study}

It has been observed, that despite the awareness created about Human Immunodeficiency Virus through various media like radio, television, postal, and health personnel, most people with this disease do present in the hospital when the disease is far advanced and often terminal (full blown AIDS).

Majority of them believe they are suffering from spiritual attack or some other diseases. This results in high rate of initial denial, following a positive HIV screening test. This prompted the researcher to use the opportunity of being a postgraduate student in nursing to determine the attitude of people in one of the community under Owo town towards HIV screening.

\section{Statement of problem}

Worldwide HIV/AIDS is one of the major causes of death, early detection through screening reduce death rate caused by this deadly disease. Awareness and cooperation from clients will make screening possible. This research will enable the researcher to know what the attitude of the people of Isuada community will be towards HIV screening. Likewise it will health educate them and the populace on the importance of HIV screening.

\section{Objectives of the study}

To identify which gender is likely to accept screening.

To examine the knowledge of the people in this community about HIV screening.

To investigate possible barriers to their accepting screening.

To correct some notion about HIV screening.

\section{Research questions}

Which gender accepts screening most?

How many of the respondents have been screened for HIV before?

How much do they know about HIV screening?

What are the possible barriers to accepting HIV screening?

Does education have effect on acceptance of HIV screening?

\section{Hypothesis}

Formal education is relatively related to positive disposition towards HIV/AIDS screening exercise.

Previous awareness is related to positive disposition to HIV screening.

Age of subject is related to awareness of HIV screening.

\section{Significance of study}

The study focuses on enlightening the public on the causes of HIV/AIDS and identifying the group(s) at risk with the aim of helping them to develop health seeking behaviour.

It further seeks to examine the attitude of Isuada community towards HIV screening exercise with a view to ascertain the group that is most accessible to the exercise.

It will also help researcher to assess the knowledge of the populace about HIV, the acceptability of screening among people as well as the barriers to accepting the screening for HIV.

It will also create an avenue for further research on the topic and as well serve as an eye opener for health workers and contribute to the pool of knowledge available on this subject matter. 


\section{Limitations and scope of the study}

The broad nature and the universal application of this study makes it practically impossible for this research project to do a thorough analysis of every sub-topic under this study.

This study was carried out among adults in Isuada community Owo Ondo State. However the findings as well as the suggestions made in the study are generalised for adults in other community under Owo, Ondo State.

\section{Definition of terms}

HIV -Human immune deficiency virus.

AIDS- Acquired immunodeficiency syndrome

HIV Screening - testing blood serum for Human immune deficiency virus antibodies

VCT: Voluntary counselling and testing

USAID: United States Agency for International Development

History of the HIV/AIDS epidemic

The Acquired Immune Deficiency Syndrome (AIDS), was first recognized among homosexual men in the United States of America. By 1983, the etiological agent, the human immunodeficiency virus (HIV), had been identified and by the mid-1980's, it became clear that the virus had spread, largely unnoticed, throughout most of the world.(UNAID, 2003).

\section{History of the HIV/AIDS epidemic with emphasis on africa}

Most of the available epidemiological data indicate that the extensive spread of HIV started in subSaharan Africa in the late 1970s. By the early 1980s, HIV was found in a geographic band stretching from West Africa across to the Indian Ocean, the countries north of the Sahara and those in the southern cone of the continent remained apparently untouched. By 1987, the epidemic began gradually to move south. Some of the most explosive epidemics have been seen in Southern Africa. South Africa has the largest number of people living with HIV/AIDS in the world, 5 million. Botswana and Swaziland have the highest prevalence levels, 38\% and 33\% respectively. West Africa has been relatively less affected by HIV infection than other regions of sub-Saharan Africa.

\section{The nigerian situation}

In Nigeria as at 2005, 2.9 million adult had HIV of which 1.9 million were women.(UNAIDS, 2007). According to this publication by the Joint United Nations Programme on HIV/AIDS, there were 1.8million HIV/AIDS orphans while 67,000-125,000 infants had HIV. More than $90 \%$ of infected children are born to HIV positive mothers. The current national HIV seroprevalence is 4.4\%.(NIGERIA NATIONAL POLICY ON HIV/AIDS. (2003)

\section{Social impact of HIV/AIDS on nigeria}

One major social effect on the society is the increasing number of orphans generated by the epidemic. Due partly to the Nigerian high total fertility rate, the large population size, and the HIV prevalence, Nigeria is estimated to have an exceedingly large number of orphans that have occurred due to AIDS. In 2001, this was estimated to be above 900,000. The social impact of this is expected to be great. There will be tremendous strain on the social systems to cope with such a large number of orphans. Many of these Nigerians may go without adequate healthcare and schooling, increasing the burden on society in future years. The children will be at risk of suffering from child abuse, prostitution and other social crimes, and they themselves may become HIV positive.

Other social effects include the increase in poverty, especially in households affected by HIV/AIDS; disruption within families and communities as they respond to issues associated with increased incidence of HIV/AIDS within their families and the communities; reduction in amount of individual and family discretionary funding for essential needs including nutrition, education, health and living conditions; and high medical, emotional, and social costs on people living with HIV/AIDS. 
Texila International Journal of Nursing

Volume 2, Issue 2, Dec 2016

Nigeria is committed to improving the quality of life of all Nigerians and this is expressed in the series of developmental plans it has embarked upon since its independence in 1960. Nigeria is again responding to the threat of the HIV/AIDS pandemic with a plan of action, when followed through, will put Nigeria on a recovery path to social and economy development.

In 1997, the Government of the Federal Republic of Nigeria, through the Federal Ministry of Health, adopted the National Policy on HIV/AIDS and STI. This was designed to limit the spread of HIV/AIDS in the country. However, this was at a time when the magnitude and widespread nature and impact of the disease was not completely recognized. For this reason, some essential components that are now known to be necessary to control the spread and the impacts of the epidemic were not adequately addressed. The resultant effect is that the HIV prevalence rate continued to rise; the number of AIDS-related deaths increased and its impact on the country worsened. The country has developed a new approach to the epidemic, ensuring that all sectors of the economy relevant to the control of the epidemic are involved in the planning, implementation and evaluation of the country's response to the epidemic. Similarly, all sectors of the economy that are affected by the epidemic are to jointly develop plans and processes to mitigate its impact. This approach will include strategies to prevent further HIV/AIDS transmission, provide care and support for the people living with HIV/AIDS and mitigate the social and economic impact of HIV/AIDS on the country (Nigerian National Policy on HIV/AIDS, 2003).

According to Haruna A. (2012), HIV is a parasite that destroys human body immune system, rendering it vulnerable to opportunistic infections, a condition known as Acquired Immune Deficiency Syndrome (AIDS). HIV/AIDS is today a global epidemic because of the devastating effects it has on human race. Current estimate shows that over 33 million people live with HIV worldwide, and Nigeria's prevalence rate and death toll hits 3.6\% and 220,000 respectively with Kano State having a record of 250,000 infected individuals (Family Health International, 2000). This figure places the country as the second most hit in the world. Consequent upon this, several coordinated measures have been used by stakeholders in curbing the spread of the epidemic. One of such measures is Voluntary Counselling and Testing (VCT). Voluntary Counselling and Testing is universally adopted as the entry point for intervention against HIV infections. It is a powerful weapon against the spread of the epidemic and Counselling and Testing (VCT).

Jennifer S. et al, (2009) observed that a significant proportion of patients with HIV/AIDS are not diagnosed until well into their disease progression. By the time they seek medical care, their immune systems are already dangerously compromised, rendering medication less effective and driving up the cost of treatment. Earlier identification offers opportunities to decrease the number of new infections in Florida each year, and earlier instigation of antiretroviral therapies offers the promise of decreasing morbidity and mortality. They also remarked that strong policies to promote HIV testing remain a vital way to help public health officials understand the populations at risk, inform on-going prevention efforts, and link infected individuals to the timely care they need.

According to Ronald B (2006), the Centres for Disease Control and Prevention (CDC) is poised to issue new recommendations for testing for HIV in adults, adolescents, and pregnant women. Frustrated that more than 25\% of Americans with HIV infection are unaware of their status and that almost $45 \%$ of those with newly diagnosed AIDS discover that they are infected less than a year before diagnosis, officials have proposed that HIV screening be routinely offered in all health care settings.

\section{Recommendations on HIV screening}

According to Ronald B (2006), the CDC already recommends routine testing among high-risk groups and in high-prevalence settings. The radical departure is the extension of routine testing to the entire population and the reconceptualization of the requirements for consent.

By 2004, according to the Kaiser Family Foundation, four states, namely Texas, Michigan, Tennessee, and Arkansas, required the testing of pregnant women unless they refused. In 13 states - 
including California, Florida, New Jersey, and Maryland, providers were required to offer pregnant women testing. Thus, the changes being proposed by the CDC and in New York grow out of more than a decade of efforts to loosen the strictures of HIV exceptionalism.

According to Henry. J. (2012), HIV testing is integral to HIV prevention, treatment, and care. Knowledge of one's HIV status is important for preventing the spread of disease. Studies show that those who learn they are HIV positive modify their behaviour to reduce the risk of HIV transmission. Early knowledge of HIV status is also important for linking those with HIV to medical care and services that can reduce morbidity and mortality and improve quality of life.

Mills EJ et al (2010), observed that in sub-Saharan Africa, HIV among older adults has largely been ignored, though there has been some emerging interest in this topic. A recent study by Negin $\mathrm{J}$ et al estimated that there are three million HIV positive people in this region aged 50 and older representing more than $14 \%$ of those over the age of 15 infected suggesting that increased attention is warranted for older age groups.

\section{Connecting individuals with HIV to care}

It is imperative that patients are linked to medical care in a timely manner once confirmed to be HIV-Positive. Prompt entry into medical care ensures that patients receive appropriate laboratory tests and disease staging. Appointments with a primary care or infectious disease specialist should be scheduled to occur within one week of a patient receiving the HIV diagnosis. Prompt assessment of health status at baseline is essential to maximize health care outcomes for newly diagnosed individual. (Rostad K et al, 2004)

According to Omary S. (2007) the role of media should be emphasized, as it appears that people get most of the information about HIV/AIDS and VCT through media such as magazines, radio, and television.

Negin. J et al (2009) said that Home-based VCT (HBVCT) is a means of improving access to testing, while simultaneously reducing the potential stigma associated with facility-based testing. HBVCT generally involves the use of lay counsellors or community health workers who provide door-to-door counselling and testing services. A recent review suggests that while HBVCT may indeed be an effective strategy for expanding access to HIV testing services,

\section{Theoretical framework}

\section{The health belief model}

Health belief model is used to explain this project work and is concerned with what people perceive, or believe, to be true about themselves in relation to their health. This model is based on three components of individual perceptions of threat of a disease which are, perceived susceptibility to a disease, perceived seriousness of a disease, and perceived benefits of action.

Acceptance of HIV screening seems to depend upon their perceiving that the screening will be of benefit to them. Perceived high personal susceptibility to HIV/AIDS, barriers related to confidentiality and partner involvement, and religion were all associated with willingness to accept voluntary HIV screening.

\section{Research methodology}

This research is a non-experimental, descriptive study on the attitude of adults towards HIV screening (a case study of Isuada community Owo, Ondo State, Nigeria).

The research study was carried out in Isuada community. Isuada community is located along OwoAkure express way, before getting to Rufus Giwa Polytechnic Owo, Owo Local Government, Ondo State, Nigeria.

The target population are the adults both males and females in Isuada community, Owo in Ondo Senatorial District. 
One hundred (100) subjects were accidentally selected, males and female of various socioeconomic background.

Sampling method used is accidental sampling, a convenient sampling method.

\section{Research instrument / method of data collection}

Questionnaires and interview methods were used in collecting relevant data from the subjects. Data were collected from subjects using closed ended questionnaires this gave the respondents opportunity to choose from series of options provided by the researcher.

The subjects who had the chance of participating in the study were selected accidentally, the purpose of the study explain to them and their consent gained, questionnaires were distributed which they find answer to. Subjects that are not literate had oral interview done.

\section{Method of data analysis}

Data collected were analysed by the use of descriptive statistical tools and same presented in tables and charts, while chi-square and correlation coefficient was used to test hypothesis and relationship between variables.

\section{Validity of the instrument}

The instrument used for data collection was able to measure the parameters it supposed to measure. ETHICAL CONSIDERATION

Informed consent gained from the subject through letter of introduction. Subjects name and address were not inclusive in collection of data. All information was treated confidential in case the subject is known.

\section{Presentation, analysis and interpretation of data.}

$\mathrm{X} / \mathrm{Y} \mathrm{X}$ 100/1 X= Number of respondents

$\mathrm{Y}=$ Total number of questionnaire

\section{Section A: Socio-Demographic Data.}

Question 1: How old are you?

Table 4.1. Distributions according to age of respondents

\begin{tabular}{|l|l|l|}
\hline \multicolumn{1}{|c|}{ Age Range } & Frequency & Percentage $\%$ \\
\hline$>20$ & 22 & 22 \\
\hline $20-39$ & 39 & 39 \\
\hline $40-59$ & 30 & 30 \\
\hline 60 and above & 9 & 9 \\
\hline Total & 100 & 100 \\
\hline
\end{tabular}

Result: The above table shows that 35 respondents representing $35 \%$ of the respondents are between 20-39 years of age which is higher than other age groups. 


\section{RESPONSE ACCORDING TO AGE}

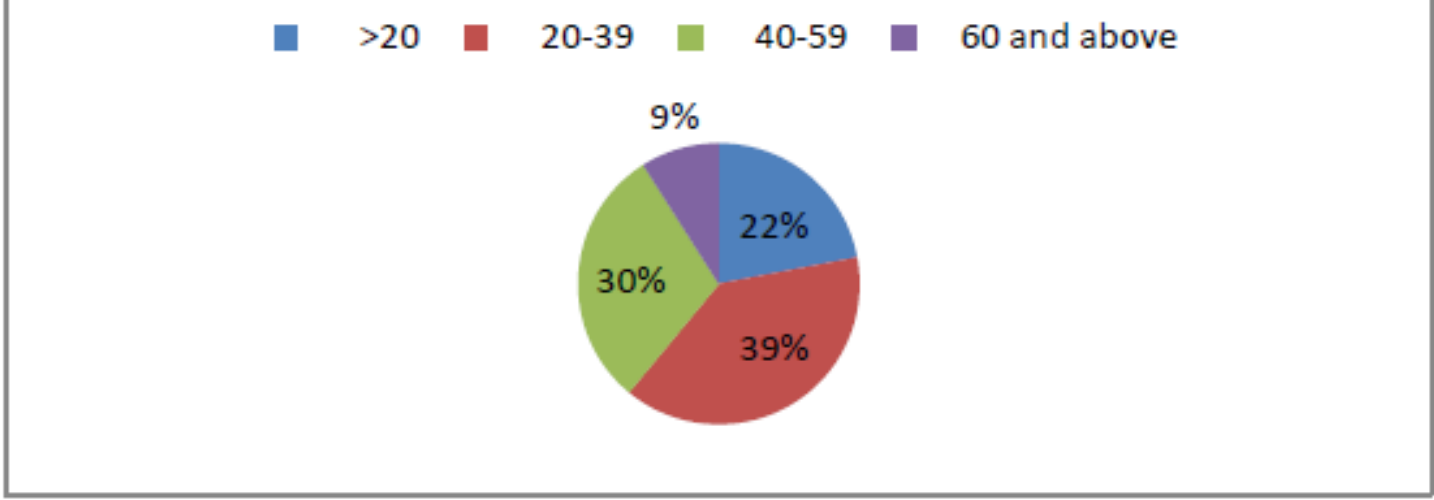

Figure 1. Pie Chart Of Distribution Of Respondents According To Age

Question 2: What is your gender?

Table 4.2 Distribution according to gender

\begin{tabular}{|l|l|l|}
\hline Gender & Frequency & Percentage \% \\
\hline Male & 48 & 48 \\
\hline Female & 52 & 52 \\
\hline Total & 100 & 100 \\
\hline
\end{tabular}

Result: The above table shows that there are 52 female (52\%) that participated in the research

\section{RESPONSE ACCORDING TO GENDER}

$$
\text { Male } \quad \text { Female }
$$

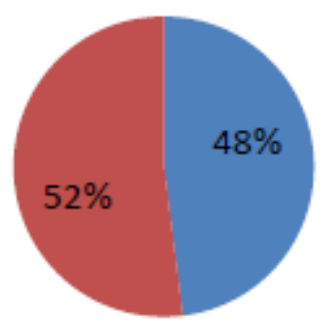

Figure 2. Distribution of Respondents According to Gender

Question 3: What is your tribe?

Table 4.3. Distribution according to tribe

\begin{tabular}{|l|l|l|}
\hline Tribe & Frequency & Percentage \% \\
\hline Yoruba & 79 & 79 \\
\hline Igbo & 3 & 3 \\
\hline
\end{tabular}




\begin{tabular}{|l|l|l|}
\hline Hausa & 00 & 00 \\
\hline Edo & 00 & 00 \\
\hline Ebira & 18 & 18 \\
\hline Total & 100 & 100 \\
\hline
\end{tabular}

Result: The table implies that 79\% of respondents were Yoruba which is higher than other tribes.

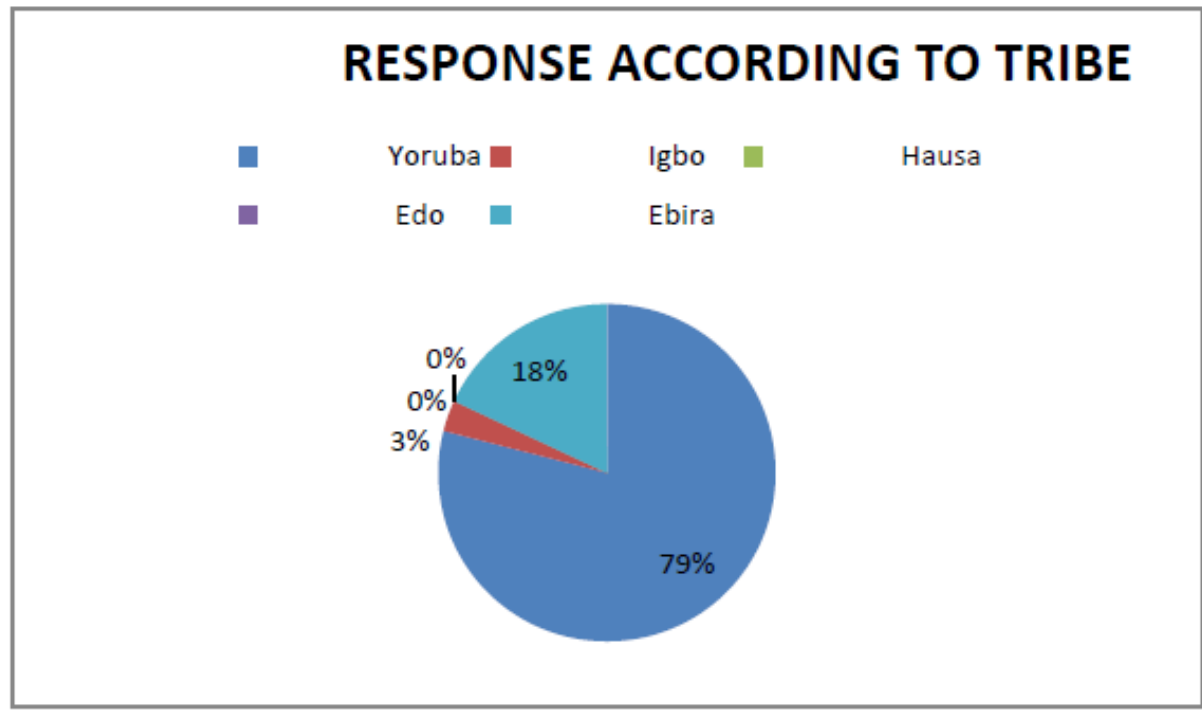

Question 4: What is your religion?

Table 4.4. Distribution according to religion

\begin{tabular}{|l|l|l|}
\hline Response & Frequency & Percentage \% \\
\hline Christianity & 85 & 85 \\
\hline Islamic & 15 & 15 \\
\hline Traditional & 00 & 00 \\
\hline Total & 100 & 100 \\
\hline
\end{tabular}

Result: This table shows that majority of the respondents are Christian (85\%) which indicate that Isuada is populated by Christians.

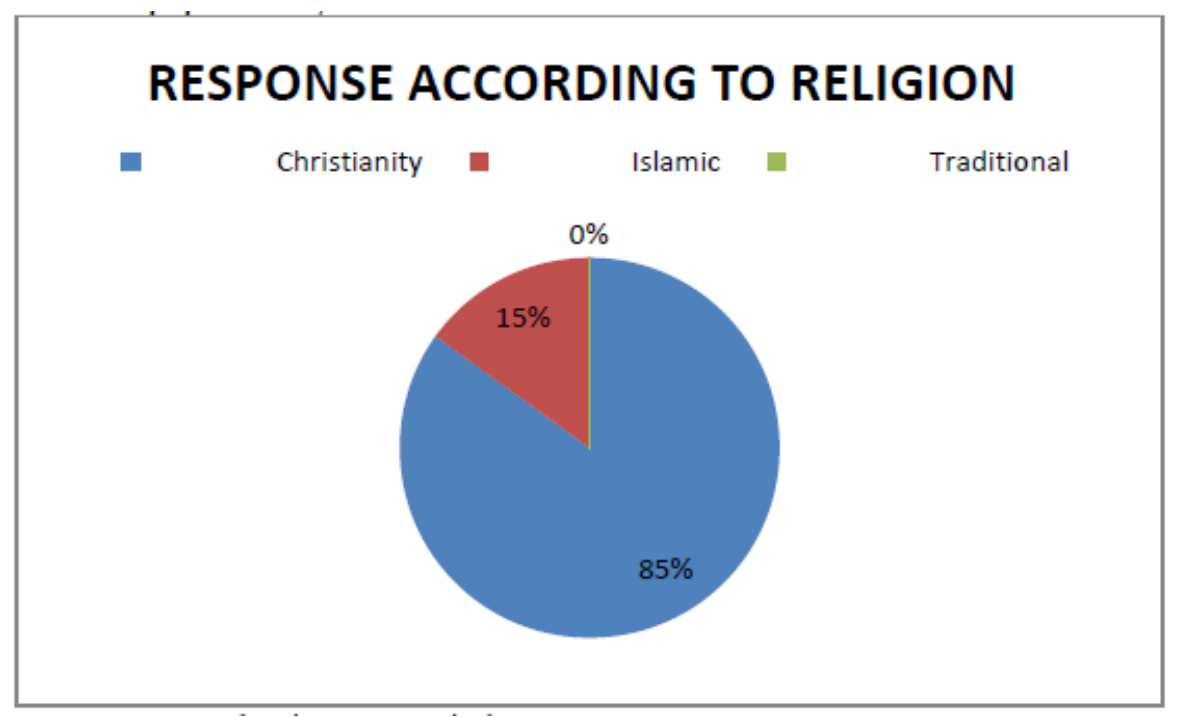

Question 5: What is your marital status? 
Table 4.5 Distribution according to marital status

\begin{tabular}{|l|l|l|}
\hline Response & Frequency & Percentage \% \\
\hline Married & 65 & 65 \\
\hline Single & 20 & 20 \\
\hline Widow & 5 & 5 \\
\hline Total & 100 & 100 \\
\hline
\end{tabular}

Result: The above table shows that $65 \%$ of the respondents are married which is the highest response.

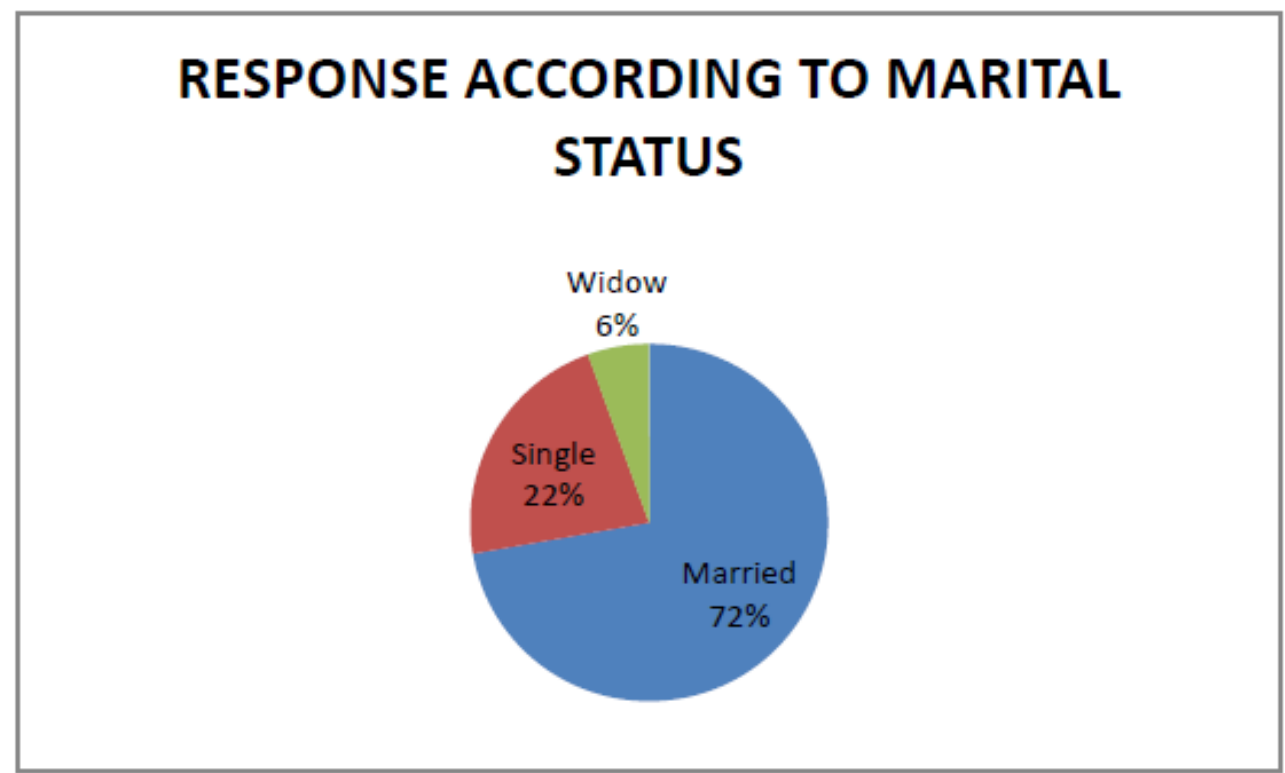

Question 6: What is your level of education?

Table 4.6 Response according to level of education

\begin{tabular}{|l|l|l|}
\hline Response & Frequency & Percentage (\%) \\
\hline Never been to school & 06 & 06 \\
\hline Primary school cert & 16 & 16 \\
\hline Secondary school cert & 41 & 41 \\
\hline OND & 18 & 18 \\
\hline Bsc/HND & 17 & 17 \\
\hline Others (pls specify) & 02 & 1 \\
\hline Total & 100 & 100 \\
\hline
\end{tabular}

Result: This table shows that the percentage of those that have secondary school certificate (41\%) is higher than other respondents. 


\section{RESPONSE ACCORDING TO LEVEL OF EDUCATION}
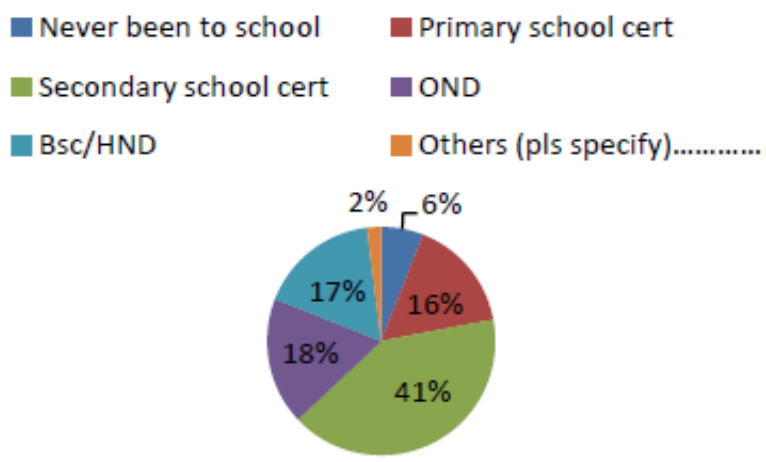

Question 7: What is your occupation?

Table 4.7 Distribution according to occupation

\begin{tabular}{|l|l|l|}
\hline Response & Frequency & Percentage \\
\hline Farming & 30 & 30 \\
\hline House wife & 2 & 2 \\
\hline Civil servant & 17 & 17 \\
\hline Trading & 23 & 23 \\
\hline Apprentice & 6 & 6 \\
\hline Student & 22 & 22 \\
\hline Total & 100 & 100 \\
\hline
\end{tabular}

Result: The table shows that the highest number of respondents were farmers (30\%).

\section{Section B: Testing Knowledge}

Question 8: Have you heard about HIV/AIDS before?

Table 4.8. Response on their hearing about HIV/AIDS

\begin{tabular}{|l|l|l|}
\hline Response & Frequency & Percentage (\%) \\
\hline Yes & 94 & 94 \\
\hline No & 6 & 06 \\
\hline Total & 100 & 100 \\
\hline
\end{tabular}

Result: The table shows that majority of respondents (94\%) have heard about HIV before. 


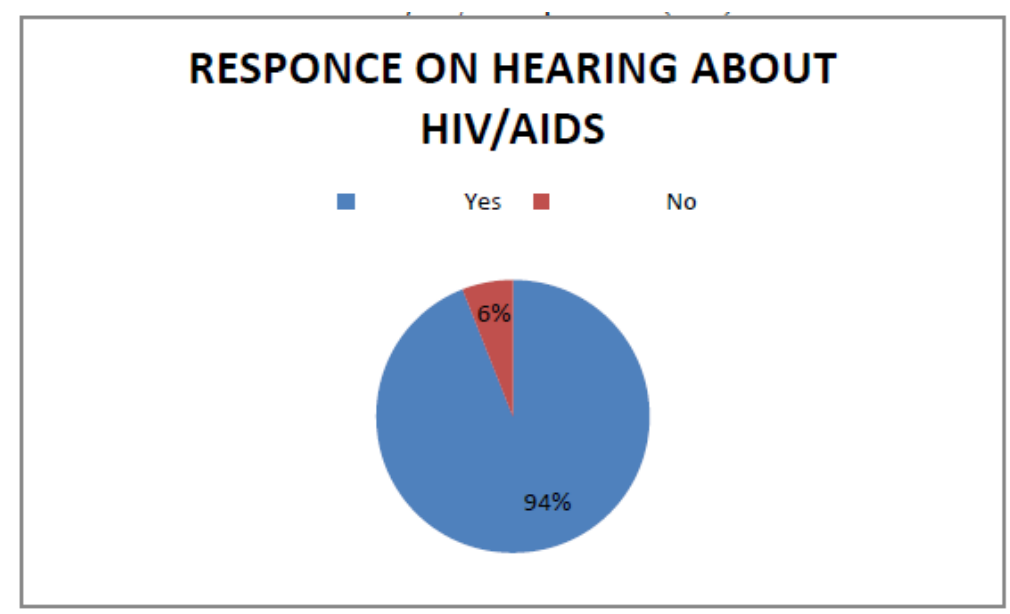

Question 9: What is your source(s) of information?

Table 4.9. Response on their source of information

\begin{tabular}{|l|l|l|}
\hline Response & Frequency & Percentage (\%) \\
\hline Health workers & 10 & 10.6 \\
\hline Radio/television & 62 & 66.0 \\
\hline Postals & 12 & 12.8 \\
\hline Friends & 10 & 10.6 \\
\hline C Total & 94 & 100 \\
\hline
\end{tabular}

Result: $66 \%$ of the respondent heard the information from either radio or television. Question 10: Have you heard about HIV screening before?

Table 4.10. Response on their hearing about HIV screening.

\begin{tabular}{|l|l|l|}
\hline Response & Frequency & Percentage \\
\hline Yes & 85 & 85 \\
\hline No & 15 & 15 \\
\hline Total & 100 & 100 \\
\hline
\end{tabular}

Result: The table shows that $85 \%$ of respondents have heard about HIV screening. Question 11: Have you been screened for HIV before?

Table 4.11 Response on their screening.

\begin{tabular}{|l|l|l|}
\hline Gender & Yes & No \\
\hline Male & 20 & 28 \\
\hline Female & 17 & 35 \\
\hline Total & 37 & 63 \\
\hline Percentage (\%) & 37 & 63 \\
\hline
\end{tabular}

Result: The table shows that $63 \%$ of the respondents have not been screened for HIV.

Table 4.11b Distribution according to gender that have been screened

\begin{tabular}{|l|l|l|}
\hline Gender & frequency & Percentage \% \\
\hline Male & 20 & 54.1 \\
\hline Female & 17 & 45.9 \\
\hline Total & 37 & 100 \\
\hline
\end{tabular}

Result: The table shows that $54.1 \%$ of respondents that have been screened before are male. 
Texila International Journal of Nursing

Volume 2, Issue 2, Dec 2016

Table 4.11c. Distribution according to gender that have not been screened

\begin{tabular}{|l|l|l|}
\hline Gender & Frequency & Percentage \\
\hline Male & 28 & 44.4 \\
\hline Female & 35 & 55.6 \\
\hline Total & 63 & 100 \\
\hline
\end{tabular}

Result: The table shows that $55.6 \%$ of respondents that have not been screened are female.

Question 12: If no why?

Table 4.12. Response on barriers to their being screened.

\begin{tabular}{|l|l|l|}
\hline Response & Frequency & Percentage \\
\hline I am afraid I will test positive & 3 & 4.76 \\
\hline I don't know where to get tested & 10 & 15.87 \\
\hline I don't like needle prick & 7 & 11.11 \\
\hline Getting tested can destabilised me & 6 & 9.52 \\
\hline I don't have enough money. & 8 & 12.70 \\
\hline I don't see need for it & 14 & 22.22 \\
\hline Not heard of it & 15 & 23.82 \\
\hline Total & 63 & 100 \\
\hline
\end{tabular}

Result: The table above shows that not hearing about the screening (23.82\%) to be the major cause of not screening for HIV.

Question 13

Table 4.13. Response to their knowledge on the spread of HIV.

\begin{tabular}{|l|l|l|}
\hline Response & Frequency & Percentage (\%) \\
\hline Yes & 29 & 30.85 \\
\hline No & 65 & 69.15 \\
\hline Total & 94 & 100 \\
\hline
\end{tabular}

Result: The table above shows $69.15 \%$ of respondent saying that AIDS is not spread by kissing Question 14: Can man infect a woman with HIV?

\begin{tabular}{|l|l|l|}
\hline Response & Frequency & Percentage (\%) \\
\hline Yes & 94 & 100 \\
\hline No & 00 & 00 \\
\hline Total & 94 & 100 \\
\hline
\end{tabular}

Result: The table shows that all the respondent $100 \%$ have the knowledge that it can be transmitted from man to woman.

Question 15: Can women infect men with HIV?

Table 4.15. Response to whether a woman can infect a man.

\begin{tabular}{|l|l|l|}
\hline Response & Frequency & Percentage (\%) \\
\hline Yes & 94 & 100 \\
\hline No & 00 & 00 \\
\hline T0tal & 94 & 100 \\
\hline
\end{tabular}

Result: The table shows that all the respondent have the knowledge that HIV can be transmitted by woman to man.

Question 16: Must a person have different sex partner to get HIV/AIDS? 
Table 4.16 Response to different sex partners

\begin{tabular}{|l|l|l|}
\hline Response & Frequency & $\begin{array}{l}\text { Percentage } \\
(\%)\end{array}$ \\
\hline Yes & 30 & 31.9 \\
\hline No & 64 & 68.1 \\
\hline Total & 94 & 100 \\
\hline
\end{tabular}

Result: The table shows that not only those that have more than one sex partner that can have HIV. Question 17: Is there any cure for HIV?

Table 4.17 Response to whether there is cure for HIV.

\begin{tabular}{|l|l|l|}
\hline Response & Frequency & percentage (\%) \\
\hline Yes & 22 & 23.4 \\
\hline No & 72 & 76.6 \\
\hline T0tal & 94 & 100 \\
\hline
\end{tabular}

Result: This shows that $76.6 \%$ believed there is no cure for HIV.

Question 18: do you know where to get tested for HIV?

Table 4.18. Response to knowledge of where to get tested.

\begin{tabular}{|l|l|l|}
\hline Response & Frequency & percentage (\%) \\
\hline Yes & 75 & 75 \\
\hline No & 25 & 25 \\
\hline Total & 100 & 100 \\
\hline
\end{tabular}

Result: The table shows that $75 \%$ of the respondents know where they can do the test Have you experience any of the following?

Question 19: Two or more sex partners?

Table 4.19. Response to their experiencing more than one sex partner.

\begin{tabular}{|l|l|l|}
\hline Response & Frequency & percentage (\%) \\
\hline Yes & 36 & 36 \\
\hline No & 64 & 64 \\
\hline Total & 100 & 100 \\
\hline
\end{tabular}

Result: The table shows that only $36 \%$ of the respondents have experienced more than one sex partner

Question 20: getting tested for HIV help people to feel better.

Table 4.20. response to effect of HIV screening on individual.

\begin{tabular}{|l|l|l|}
\hline Response & Frequency & Percentage \% \\
\hline Strongly agreed & 27 & 27 \\
\hline Agreed & 39 & 39 \\
\hline Undecided & 12 & 12 \\
\hline Disagreed & 14 & 14 \\
\hline $\begin{array}{l}\text { Strongly } \\
\text { disagreed }\end{array}$ & 8 & 8 \\
\hline Total & 100 & 100 \\
\hline
\end{tabular}

Result: The table shows that $39 \%$ of the respondents agreed that HIV screening will make somebody to feel better.

Question 21: getting tested for HIV help prevent others from getting HIV. 
Texila International Journal of Nursing

Volume 2, Issue 2, Dec 2016

Table 4.21. Response to preventive effect of HIV screening.

\begin{tabular}{|l|l|l|}
\hline Response & Frequency & Percentage \\
\hline Strongly agreed & 28 & 28 \\
\hline Agreed & 34 & 34 \\
\hline Undecided & 16 & 16 \\
\hline Disagreed & 15 & 15 \\
\hline Strongly disagreed & 7 & 7 \\
\hline Total & 100 & 100 \\
\hline
\end{tabular}

Result: More than half of the respondent agreed that HIV is preventable.

Question 22: will you be willing to get tested for HIV?

Table 4.22

\begin{tabular}{|c|c|c|}
\hline \multicolumn{3}{|c|}{$\begin{array}{l}30 \text { RESPONSE TO WILLINGNESS TO GET TESTED } \\
\text { FOR HIV. }\end{array}$} \\
\hline Response & frequency & Percentage \\
\hline Strongly agreed & 20 & 20 \\
\hline Agreed & 50 & 50 \\
\hline Undecided & 15 & 15 \\
\hline Disagreed & 7 & 7 \\
\hline Strongly disagreed & 8 & 8 \\
\hline Total & 100 & 100 \\
\hline
\end{tabular}

Result: The table shows that $50 \%$ of the respondents agreed that they should be tested for HIV.

While 20\% strongly agreed to it

Question 23: will you want your spouse to be tested?

Table 4.23. Response to spouse getting tested

\begin{tabular}{|l|l|l|}
\hline Response & Frequency & Percentage (\%) \\
\hline Strongly agreed & 29 & 29 \\
\hline Agreed & 45 & 45 \\
\hline Undecided & 14 & 14 \\
\hline Disagreed & 6 & 6 \\
\hline Strongly disagreed & 6 & 6 \\
\hline Total & 100 & 100 \\
\hline
\end{tabular}

\section{Result}

The table shows that $45 \%$ of respondents are willing that their spouse should be tested.

\section{Major findings and interpretation}

The findings of the research revealed that the majority of the respondents are within the age range of 20-39 years (39\%) and ages 40-59 (30\%). This shows that the majority of the respondents are in age when they are sexually active and must have been exposed to HIV risk factors. This is in support of the study of Negin et al (2011) reveals that people aged 50 years and older have lower levels of HIV related knowledge and awareness than those aged 25-49. Older adults were less likely to have been tested for HIV.

The data analysis also shows that many of the respondents have basic education background; this can be seen in number of people that had secondary school background (41\%). This shows that they are literate to some extent. 
Table 4.8 shows that $94 \%$ of respondents have heard about HIV before through various media in which radio and television (66.8\%) is the major source. This shows that as farmers they still have the opportunity to listen to news on the farm through their pocket radio and language is not a barrier.

According to Omary S. (2007) the role of media should be emphasized, as it appears that people get most of the information about HIV/AIDS and VCT through media such as magazines, radio, and television.

Out of the 100 respondents 52\% were females as seen in figure 4.2. The majority (96\%) of these respondents knew that HIV can be transmitted from one sex to the other.

In table 4. a large proportion (75\%) of the respondents knew where to get tested (federal hospitals), but only a few (37\%) of them ever had HIV test done for them.

Of those who ever used VCT services $54.1 \%$ were male seen in figure $4.11 \mathrm{~b}$. This is as a result of HIV screening done by them prior blood donation when their relations needed blood transfusion it is in support of Henry, J. et al., (2004) HIV testing is mandatory in the U.S. in certain cases, including for: blood and organ donors, military applicants and active duty personnel, federal and state prison inmates under certain circumstances; and newborns in some states.

Figure 4.11c shows that $55.6 \%$ of respondents that were not screened were female this is as a result of poor utilization of government hospitals their women either deliver at home or they visit traditional birth attendant. according to the Kaiser Family Foundation, four states - Texas, Michigan, Tennessee, and Arkansas, required the testing of pregnant women unless they refused.

For those who never used VCT services (23.85\%) said they don't know where to get tested, and 22.2\% said they don't see the need for it. Negin. J et al (2009) said that Home-based VCT (HBVCT) is a means of improving access to testing, while simultaneously reducing the potential stigma associated with facility-based testing. HBVCT generally involves the use of lay counsellors or community health workers who provide door-to-door counselling and testing services.

\section{Answers to research questions}

Question 1

Which gender accepts screening most?

Answer: Table 4.11c shows that the males accepted screening more readily than females.

Question 2

How many of the respondents have been screened for HIV before?

Answer: In figure 4.11a of data analysis 37\% of the respondents have been screened for HIV before. $54.1 \%$ of those screened were male. This shows that the men at one time have had cause to donate blood.

Question 3

How much do they know about HIV screening?

Answer: According to table 4.10 majority of the respondents have heard about HIV screening before $85 \%$. Likewise $75 \%$ knows where to get tested (table 4.20)

Question 4

What are the possible barriers to accepting HIV screening?

Answer: According to figure 4.12 some respondents said that they don't know there is screening for HIV 23.85\%, while some does not see any need for it 22.22.

Question 5

Does education have effect on acceptance of HIV screening?

Answer: In figure 4.6 the largest part $41 \%$ of respondents have secondary school background. This indicates that education is not a barrier to accepting HIV screening. In figure 4.20 respondents that strongly agreed to HIV screening were $20 \%$ and those that agreed were $50 \%$.

\section{Summary}

This is a survey research on attitude of adult in Isuada community Owo Ondo state towards HIV screening. 
Texila International Journal of Nursing

Volume 2, Issue 2, Dec 2016

The study shows the willingness of the majority of the people of Isuada community to be screened and possible reasons for their not been screened, which include, lack of fund and fear of testing positive.

It is believed that HIV/AIDS and screening for it, is feared by majority of Nigerians, intensive health education and screening outreach can change their notion about HIV screening.

\section{Conclusion}

Conclusively, the study had demonstrated the acceptance of HIV screening among adults in Isuada community Owo. The community health centres and our traditional birth attendance should not be left out in their involvement in HIV screening so that everyone will know their status and commenced treatment as need be.

Poverty is one of the hindrances to screening the government should introduce free HIV screening to all level in health care system.

\section{Recommendation}

The government should introduce free screening exercise to people in the community so that there will be free asses to screening.

Training of traditional birth attendant on importance of HIV screening and the procedure should be done by our government.

Health workers and social workers should be encouraged to work in community so that the less privileged and the illiterate will have asses to health care.

\section{References}

[1]. Barbacci MB, Dalabetta GA, Repke JT, et al. Human immunodeficiency virus infection in women attending an inner-city prenatal clinic: ineffectiveness of targeted screening. 1990;17(3):122-6.

[2]. Boon H, Ruiter RAC, James S, Van Den Borne B, Williams E, Reddy P. The impact of a communitybased pilot health education intervention for older people as caregivers of orphaned and sick children as a result of HIV and AIDS in South Africa. J Cross Cult Gerontol. 2009;24(4):373-89.

[3]. Connor EM, Sperling RS, Gelber R, et al. Reduction of maternal-infant transmission of human immunodeficiency virus type 1 with zidovudine treatment. Pediatric AIDS Clinical Trials Group Protocol 076 Study Group. N Engl J Med1994;331(18):1173-80.

[4]. Ellerbrock TV, Lieb S, Harrington PE, et al. Heterosexually transmitted human immunodeficiency virus infection among pregnant women in a rural Florida community. N Engl J Med 1992;327(24):1704-9.4.

[5]. Federal Ministry of Health, Nigeria (2006). The 2005 National HIV Sero-prevalence Sentinel Survey among pregnant women attending antenatal clinics in Nigeria.

[6]. Joel Negin et al. HIV Attitudes, Awareness and Testing Among Older Adults in Africa. AIDS

Behav.2012; 16(1):63-68.

[7]. Joint United Nations Programme on HIV/AIDS(UNAIDS):AIDS Epidemic update: December 2007

[8]. Postma MJ, Beck EJ, Hankins CA, et al. Cost-effectiveness of expanded antenatal HIV testing in London. AIDS 2000;14(15):2383-9.

[9]. Kipp WE, Alibhai A, Saunders D, Konde-Lule J, Ruhunda A. Public knowledge and attitudes toward HIV/AIDS and antiretroviral therapy in Kabarole district, western Uganda. AIDS Care. 2009;21(1):118-24. [10]. Landesman S, Minkoff H, Holman S, McCalla S, Sijin O. Serosurvey of human immunodeficiency virus infection in parturients. Implications for human immunodeficiency virus testing programs of pregnant women. JAMA 1987;258(19):2701-3.

[11]. Lindsay MK, Peterson HB, Feng TI, Slade BA, Willis S, Klein L. Routine antepartum human immunodeficiency virus infection screening in an inner-city population. Obstet Gynecol 1989;74(3 Pt 1):28994.

[12]. Negin J, Cumming RG. HIV infection in older adults in subSaharan Africa: extrapolating prevalence from existing data. Bull World Health Organ. 2010;88:847-53. 
Texila International Journal of Nursing

Volume 2, Issue 2, Dec 2016

[13]. Revised recommendations for HIV screening of pregnant women. MMWR Recomm Rep 2001;50(RR19):63-85; quiz CE1-19a2-CE6-19a2.

[14]. Savasta AM. HIV: associated transmission risks in older adults— an integrative review of the literature. J Assoc Nurses AIDS Care.2004;15(1):50-9.

[15]. United Nation Children Fund (UNICEF). State of world children 2009 New York, UNICEF, 2008 (http://www.unicef.org/sowc09/index.php, accessed 18th October, 2009).

[16]. Workshop on HIV/AIDS and adult mortality in developing countries, Population Division Department of Economic and Social Affairs United Nations Secretariat New York, 8-13 Sept 2003 